\title{
Determination of sugars in royal jelly by HPLC1
}

\author{
Giulio SESTA* \\ C.R.A., Istituto Sperimentale per la Zoologia Agraria, Sezione di Apicoltura, Via L. Rech 36, 00156 Rome, Italy \\ Received 19 May 2005 - revised 2 August 2005 - accepted 3 August 2005
}

\begin{abstract}
A HPLC method with refractive index detection (RID) was developed for sugar determination in royal jelly (RJ). The method enables the determination of the three main sugars of royal jelly (fructose, glucose and sucrose), and maltose, which is sometimes present in RJ. The method ensures adequate sensitivity, quantitative recoveries, does not suffer from matrix interferences and shows good repeatability. It was used for the analysis of $97 \mathrm{RJ}$ samples of different origin and the results were found to be in agreement with those reported in literature. The method is simple and suitable for a routine quality control of RJ sugar composition and represents an alternative to gas chromatographic methods, which require more complex purification and derivatisation steps.
\end{abstract}

royal jelly / sugars / HPLC

\section{INTRODUCTION}

Among bee products, honey is the only one for which composition and quality standards have been defined and subjected to international standards (Codex Alimentarius, 2001; European Commission, 2002). Such standards are of the highest importance for market exchanges and consumer protection. Other bee products are lacking official standards or even internationally recognised definitions for the products themselves.

The need for international quality standards is particularly important for royal jelly (RJ), a product employed as a diet integrator, mainly for children, elderly or convalescent people.

The problem of RJ quality and consumer's safeguard was taken into account at the Apimondia International Honey Commission (IHC, 2003) and at the Italian organisation for standardisation (UNI), where working groups were set up to provide a harmonised definition of the

\footnotetext{
* Corresponding author: giulio.sesta@ apicoltura.org
}

${ }^{1}$ Manuscript editor: Klaus Hartfelder product, to establish physicochemical parameters useful as quality standards and to propose analytical methods suitable for routine control. In the "Manuel suisse des denrées alimentaires" there is a chapter on RJ where indicative composition values are reported (Bogdanov et al., 2004).

The most characteristic compound of RJ is trans-10-hydroxy-2-decenoic acid (10-HDA). No other natural product has been reported to contain 10-HDA and so, being specific to RJ, 10 -HDA represents the main criterion in quality control for the determination of RJ authenticity (Bloodworth et al., 1995).

The composition of RJ has been studied by several authors, but data available in the literature are highly variable, partly due to an intrinsic variability of the product and partly as a result of the use of different analytical methods. According to Piana (1996) the main components of RJ are water (57-70\%), sugars, mainly fructose, glucose and sucrose (18-52\% dry 
weight, corresponding to about $6-18 \%$ on fresh matter), proteins (17-45\% d.w.), lipids (3.5-19\% d.w.) and minerals (2-3\% d.w.). For fresh RJ, Bogdanov et al. (2004) reported the composition as: water $60-70 \%$, sugars $11-$ $23 \%$, proteins (9-18\%), lipids (4-8\%) and minerals $(0.8-3 \%)$.

Besides being among the main components, sugars may also be a parameter for the detection of possible RJ adulteration with honey or sugars (Serra Bonvehi, 1991). Therefore, their determination is a significant part of the RJ quality control.

Until now, both gas chromatographic and enzymatic methods were developed for the determination of RJ sugar composition. The gas chromatographic methods (Lercker et al., 1986; Pourtallier et al., 1990; Serra Bonvehi, 1992) require various purification and derivatisation steps and the use of an internal standard. The enzymatic method, developed by Tourn et al. (1980), is rather laborious because it requires a separate determination for each sugar. Moreover, the enzymatic determination of sucrose is not very reliable in the presence of high amounts of glucose (which is always the case for RJ), because sucrose is calculated by the difference of glucose content before and after invertase hydrolysis of the disaccharide.

A simple HPLC method is proposed here that requires common laboratory equipment, such as a refractive index detector (RID) and simple reagents and glassware. The method enables to the assessment of the three main sugars in RJ: fructose, glucose and sucrose, and also allows the determination of maltose, which is sometimes found in RJ, and may represent an adulteration indicator (Serra Bonvehi, 1991). The chromatographic determination is an HPLC analysis with refractive index detection, analogous to the analysis of sugars in honey (Bogdanov and Baumann, 1988; Bogdanov et al., 1997b), but the sample preparation was developed for the application to a matrix (RJ) that requires more complex processing, due to its composition that includes proteins and lipids, absent in honey. The HPLC analysis is carried out on a water/methanol solution of RJ, after protein precipitation by means of Carrez reagents (Bogdanov et al., 1997a) and lipid removal by extraction with dichloromethane.

\section{MATERIALS AND METHODS}

\subsection{Samples}

The method was carried out on $97 \mathrm{RJ}$ samples of different origin: 79 samples came from the experimental apiaries of the Istituto Sperimentale per la Zoologia Agraria near Rome. Fifty-one samples were produced from April to July 2003, and 28 samples from May to September 2004. Thirteen samples were provided by Italian producers and 5 samples originating from foreign countries (mainly China) were provided by importers. All the samples were kept refrigerated at $4{ }^{\circ} \mathrm{C}$ before analysis, and analyzed within 3 months of their production or arrival.

\subsection{Method}

\subsubsection{Sample preparation}

Two $\mathrm{g}$ of crude RJ was placed in a $10 \mathrm{~mL}$ volumetric flask, and a water/methanol solution (3:1) was added to make a final volume in the flask of no more than $9 \mathrm{~mL}$, Flask contents were mixed. To weigh the RJ sample directly in the small $10 \mathrm{~mL}$ flask, a $5 \mathrm{~mL}$ plastic pipette tip was used: part of the bottom end of the pipette tip was cut away and the top end inserted in a rubber pipette filler. Then the RJ sample, already homogenized with a metal spatula, was drawn into the pipette tip and easily delivered into the volumetric flask. Alternatively, a $3 \mathrm{~mL}$ polyethylene disposable Pasteur pipette can be used, after cutting away part of the tip.

Optionally, to include a surrogate standard, $0.2 \mathrm{~mL}$ of a solution composed of $5 \mathrm{~g}$ of xylose and $25 \mathrm{~mL}$ of a $3: 1$ solution of water/methanol was added. This gave a final xylose concentration of $4 \mathrm{mg} / \mathrm{mL}$.

A $0.2 \mathrm{~mL}$ volume of Carrez I reagent (distilled water solution of potassium hexacyanoferrate(II), $\left.\mathrm{K}_{4} \mathrm{Fe}(\mathrm{CN})_{6} \cdot 3 \mathrm{H}_{2} \mathrm{O}, 15 \mathrm{~g} / 100 \mathrm{~mL}\right)$ was added and mixed. Subsequently, a $0.2 \mathrm{~mL}$ volume of Carrez II reagent (distilled water solution of zinc acetate, $\mathrm{Zn}\left(\mathrm{CH}_{3} \mathrm{COO}\right)_{2} \cdot 2 \mathrm{H}_{2} \mathrm{O}, 30 \mathrm{~g} / 100 \mathrm{~mL}$ ) was added and mixed. The flask was then filled to $10 \mathrm{~mL}$ volume with the water/methanol solution and mixed. The solution was transferred to a $10 \mathrm{~mL}$ glass centrifuge vial and centrifuged at $4000 \mathrm{rpm}$ for 15 minutes to remove the protein fraction.

An aliquot of $5 \mathrm{~mL}$ of the supernatant was transferred to a $10 \mathrm{~mL}$ glass vial (provided with cap) that had been pre-washed with dichloromethane. Four to $5 \mathrm{~mL}$ of dichloromethane was added, the vial was capped and shaken and then vortexed vigorously for at least two minutes. The two layers were allowed to separate and the upper layer (containing the sugar fraction) was collected with a Pasteur pipette. Two 
additional extractions were performed on this sugar fraction as described above. Following the third extraction, the sugar fraction was filtered through a $0.45 \mu \mathrm{m}$ disposable syringe filter (e.g. Whatman Puradisc 25AS, polysulfone filter media). The sample was refrigerated and used for HPLC injection within 3 days.

\subsubsection{HPLC analysis}

The following instrumentation was used for HPLC analysis: autosampler/injector (Varian Prostar model 400), pump (Varian model 230), column thermostat (DBS PCO-200 Peltier System), detector (Varian RI-4 refractive index detector), software (Varian Star Chromatography Workstation Version 6.00), column (Restek Pinnacle II Amino, $5 \mu \mathrm{m}$, $250 \times 3.2 \mathrm{~mm}$ ). Elution was performed using acetonitrile/water (85:15) as the mobile phase, at a flow rate of $1.4 \mathrm{~mL} / \mathrm{min}$. The column and the refractive index detector were maintained at $30^{\circ} \mathrm{C}$. The injection volume was $5 \mu \mathrm{L}$.

Qualitative and quantitative determination was based on the injection of an external standard prepared as follows: $100 \mathrm{~mL}$ water/methanol solution (3:1) containing $1.1 \mathrm{~g}$ of fructose, $1.1 \mathrm{~g}$ of glucose, $0.3 \mathrm{~g}$ of sucrose and $0.3 \mathrm{~g}$ of maltose. The resulting concentrations reflected a common sugar composition of RJ. Results are expressed as a weight/weight percentage $(\mathrm{g} / 100 \mathrm{~g})$ of each sugar on the crude RJ. If the surrogate standard was used then the xylose peak was quantified by the injection of an external standard solution at a concentration of $4 \mathrm{mg} / \mathrm{mL}$.

\subsubsection{Blank, recovery and repeatability tests, limit of detection}

Method blanks were performed by executing the complete sample preparation and HPLC analysis on the water methanol solution in the $10 \mathrm{~mL}$ volumetric flask without adding any RJ sample or surrogate standard solution. Six method blanks were performed as initial demonstrations of the absence of method interferences. A method blank was performed for every batch of samples analyzed.

Recovery tests were performed on a reference sample (mixture of known quantities of sugars) weighed in the $10 \mathrm{~mL}$ volumetric flask and processed as a RJ sample ( 9 replicates). To obtain the reference sample, a homogenous mixture of $11.0 \mathrm{~g}$ of fructose, $11.0 \mathrm{~g}$ of glucose, $3.0 \mathrm{~g}$ of sucrose and $3.0 \mathrm{~g}$ of maltose was prepared and 9 aliquots of $0.5 \mathrm{~g}$ of this mixture were put into 9 volumetric flasks. The entire sample preparation and chromatographic analysis were then performed on these nine aliquots.

The repeatability of the method for fructose, glucose and sucrose was tested by analyzing 10 aliquots

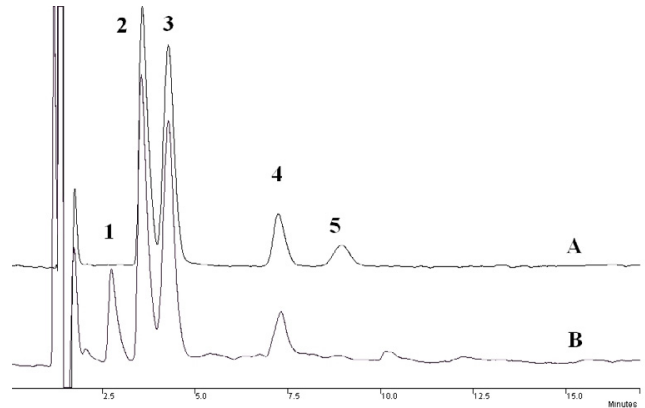

Figure 1. Chromatograms of a sugar external standard solution (A) and a RJ sample (B). 1: xylose; 2 fructose; 3: glucose; 4: sucrose; 5: maltose. Chromatographic conditions: column: Restek Pinnacle II Amino, $5 \mu \mathrm{m}, 250 \times 3.2 \mathrm{~mm}$; mobile phase: acetonitrile/water (85:15), isocratic; flow rate: $1.4 \mathrm{~mL} /$ min; detector: refractive index detector; column and detector temperature: $30^{\circ} \mathrm{C}$; injection volume: $5 \mu \mathrm{L}$.

of the same RJ sample. The repeatability of the maltose determination was evaluated on a different RJ sample (maltose is seldom found in $\mathrm{RJ}$ ) and six replicate analyses were performed.

The recovery and repeatability of the surrogate standard was studied by analyzing 15 different RJ samples spiked with xylose as described in Section 2.2.1.

The method detection limit, expressed on crude royal jelly, was calculated by injecting 7 aliquots of a water/methanol 3:1 solution spiked at $0.2 \mathrm{mg} / \mathrm{mL}$ (equivalent to a concentration in RJ of $0.1 \mathrm{~g} / 100 \mathrm{~g}$ ) for each sugar (fructose, glucose, sucrose and maltose). The resulting chromatograms were integrated, and the average concentration and standard deviations were calculated. The detection limit for each sugar was calculated multiplying the standard deviation value obtained by the $99 \%$ confidence level Student's t-value relative to the number of degrees of freedom $(7-1=6)$.

The detector linearity was tested by injecting 5 sugars solutions at $0.2,1.0,5.0,10.0$ and $20.0 \mathrm{mg} / \mathrm{mL}$ (corresponding to $0.1,0.5,2.5,5$ and $10 \mathrm{~g} / 100 \mathrm{~g}$ in $\mathrm{RJ}$ ) containing the four sugars (fructose, glucose, sucrose and maltose). The linear correlation coefficient $\mathrm{R}^{2}$ was 0.998 or better for all four sugars.

\section{RESULTS AND DISCUSSION}

The resolution was adequate for the target sugars and both method blanks and RJ chromatograms show no significant interferences (Fig. 1). Recovery tests performed on 9 reference samples showed quantitative and constant 
Table I. Results of the repeatability study. The sugar concentrations are expressed as weight/ weight percentages on the crude sample $(\mathrm{RSD}=$ relative standard deviation).

\begin{tabular}{lcccc}
\hline & $\begin{array}{c}\text { No. of } \\
\text { replicates }\end{array}$ & $\begin{array}{c}\text { Average } \\
(\mathrm{g} / 100 \mathrm{~g})\end{array}$ & $\begin{array}{c}\text { St dev } \\
(\mathrm{g} / 100 \mathrm{~g})\end{array}$ & $\begin{array}{c}\text { RSD } \\
\%\end{array}$ \\
\hline Fructose & 10 & 6.39 & 0.16 & 2.5 \\
Glucose & 10 & 5.94 & 0.12 & 2.1 \\
Sucrose & 10 & 1.26 & 0.03 & 2.2 \\
Maltose & 6 & 2.61 & 0.02 & 0.8 \\
\hline
\end{tabular}

Table II. Results of the detection limit study.

\begin{tabular}{|c|c|c|c|}
\hline & $\begin{array}{l}\text { Average } \\
(\mathrm{g} / 100 \mathrm{~g})\end{array}$ & $\begin{array}{l}\text { t. dev. }(\mathrm{n}=7) \\
(\mathrm{g} / 100 \mathrm{~g})\end{array}$ & $\begin{array}{l}\text { Detection limit } \\
\left(\text { St. dev } t_{v=6 ; 99 \%)} \text { ) }\right.\end{array}$ \\
\hline Fructose & 0.126 & 0.019 & 0.059 \\
\hline Glucose & 0.115 & 0.018 & 0.056 \\
\hline Sucrose & 0.096 & 0.013 & 0.039 \\
\hline Maltose & 0.106 & 0.019 & 0.061 \\
\hline
\end{tabular}

recoveries for the four sugars. The following values were obtained for average recovery and standard deviation: $100.6 \% \pm 3.6 \%$ for fructose, $97.2 \% \pm 3.9 \%$ for glucose, $101.4 \% \pm 4.1 \%$ for sucrose, $95.3 \% \pm 3.7 \%$ for maltose. The results of the repeatability test are reported in Table I and showed adequate performance of the method for all four sugars. The sensitivity of the method was adequate, as the detection limit for all four sugars was $0.06 \mathrm{~g} / 100 \mathrm{~g}$ on crude RJ or better (Tab. II).

The method allows the use of a surrogate standard although its use was not essential for the determination because of the quantitative recoveries resulting from the sample preparation. The advantage of using a surrogate standard is that it enables monitoring of sugar recovery directly for each sample, to detect possible errors in sample preparation. The compound chosen as surrogate standard was xylose. Several other sugars were investigated for their possible use as surrogate standards (arabinose, mannitol, lactose, see Fig. 2), but xylose was chosen for several reasons. First, xylose has not been reported to occur naturally in RJ in significant amounts. Secondly, as a monosaccharide, it is representative of the behavior of fructose and glucose, the two most

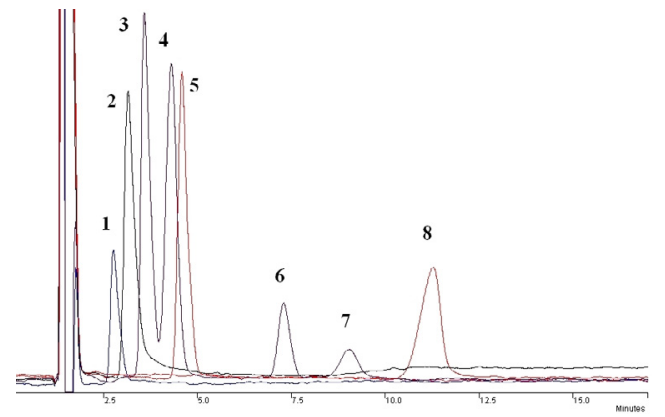

Figure 2. The four sugars, xylose (1), arabinose (2), mannitol (5) and lactose (8), that were evaluated for their possible use as surrogate standard shown together with the four sugars analysed, fructose (3), glucose (4), sucrose (6) and maltose (7). Chromatographic conditions: column: Restek Pinnacle II Amino, $5 \mu \mathrm{m}, 250 \times 3.2 \mathrm{~mm}$; mobile phase: acetonitrile/water (85:15), isocratic; flow rate: $1.4 \mathrm{~mL} /$ min; detector: refractive index detector; column and detector temperature: $30^{\circ} \mathrm{C}$; injection volume: $5 \mu \mathrm{L}$.

abundant RJ sugars. Further, xylose's peak can be resolved from the other sugar peaks. In comparison, the peaks of arabinose and mannitol partially overlap with fructose and glucose, respectively. Lactose, whose peak falls after maltose, might be a second choice to evaluate the recovery of the disaccharides sucrose and maltose. However lactose, being eluted late and isocratically, results in a rather broad peak. This feature increases the potential for errors in integration and requires use of a high concentration of lactose, which might be a problem because of the limited solubility of lactose in hydroalcoholic solution. The final concentration of xylose in the sample solution was $4 \mathrm{mg} / \mathrm{mL}$, less than half of the usual fructose and glucose concentration in RJ samples. In this way, the peak of the surrogate standard is narrow and short enough not to disturb the integration of the following fructose peak but, being the first eluted sugar, it is still a sharp and tall enough peak to ensure reliable quantification and recovery verification. The average recovery of xylose was $95.3 \%$ with a standard deviation of $3.5 \%$.

The described chromatographic conditions ensured adequate resolution for the four sugars. Analogous chromatographic results were obtained by using a different column diameter ( $250 \mathrm{~mm} \times 4.6 \mathrm{~mm}, 5 \mu \mathrm{m}$ silica particles diameter) at a higher flow rate $(2.4 \mathrm{~mL} / \mathrm{min})$ and 
Table III. Results (g/100 g) of sugar analyses performed on $97 \mathrm{RJ}$ samples with the described method (as maltose is less frequently found than the three main sugars, its determination started in a subsequent period. So maltose was determined in 41 samples while fructose, glucose and sucrose in 97 samples).

\begin{tabular}{lccccc}
\hline & Fructose & Glucose & Sucrose & Maltose & GI + Fr + Su \\
\hline No. of samples & 97 & 97 & 97 & 41 & 97 \\
Average $(\mathrm{g} / 100 \mathrm{~g})$ & 4.6 & 5.8 & 1.0 & 0.4 & 11.4 \\
Std dev $(\mathrm{g} / 100 \mathrm{~g})$ & 1.0 & 1.0 & 0.6 & 0.7 & 2.0 \\
Max $(\mathrm{g} / 100 \mathrm{~g})$ & 6.9 & 8.2 & 2.1 & 3.1 & 16.0 \\
Min $(\mathrm{g} / 100 \mathrm{~g})$ & 2.3 & 3.7 & $<0.1$ & $<0.1$ & 6.9 \\
\hline
\end{tabular}

employing a larger injection volume $(10 \mu \mathrm{L})$. The $3.2 \mathrm{~mm}$ column diameter was selected to minimize solvent consumption. The $85 \%$ acetonitrile mixture (rather rich in organic component) ensures adequate separation between xylose and fructose (if the surrogate standard option is not adopted an $80 \%$ mixture can be used with a slight improvement in analysis time). The $1.4 \mathrm{~mL} / \mathrm{min}$ flow rate (rather high for this column format) guaranteed fast analysis times and good peak shapes, while maintaining adequate peak resolution. The injection volume of $5 \mu \mathrm{L}$ gave sharp and resolved peaks, while a volume of $10 \mu \mathrm{L}$ or more proved to be excessive (peak broadening and doubling).

This HPLC-RID method was applied to 97 different RJ samples. The average concentrations found are reported in Table III and are comparable with sugar levels reported in the literature (Lercker et al., 1992; Serra Bonvehi, 1992; Piana, 1996).

\section{CONCLUSIONS}

The need for quality standards related to bee products other than honey is widely recognised, both for consumer safety and for the enhancement of European beekeeping through value-added products. For royal jelly, sugars are among the main components, and their quantification is of evident interest for quality control, including the detection of possible adulteration with honey or sugars. Fructose, glucose and sucrose are by far the main sugars in RJ, and a possible standard for this product will most likely concern, among composition criteria, these three sugars, as is the case for honey international standards.
The proposed method for the determination of the main RJ sugars is easily applicable in a laboratory equipped for the HPLC determination of sugars in honey and shows adequate sensitivity. Sample processing is much less intensive than for GC methods, does not require derivatisation steps and there's no need for an internal standard. Nevertheless the method allows the use of a surrogate standard (xylose) as a tool for the quality control of analytical performance. Although the sensitivity may be not sufficient for determining other oligosaccharides possibly present in RJ at trace levels, the described method is surely suitable and adequate for a routine quality control of royal jelly, and represents a valid alternative to other more complex methods.

\section{ACKNOWLEDGEMENTS}

The author thanks Dr Lorenzo Natale, Laboratorio chimico merceologico, Camera di Commercio di Roma, for making available his instrumentation for some trials. This research is part of the project BIOGEL, financed by the Ministero delle Politiche Agricole e Forestali.

Résumé - Détermination des sucres de la gelée royale par HPLC. Il n'existe pas de normes de qualité reconnues internationalement pour les produits du rucher, mis à part le miel. De telles normes sont particulièrement importantes pour la gelée royale (GR), dont la production est en augmentation dans les pays européens. Un paramètre important de la qualité de la GR est la composition en glucides qui était, jusqu'à présent déterminée par chromatographie en phase gazeuse (GC). La GC nécessite une purification, une double dérivation et l'utilisation d'un standard interne, ce qui est plus adapté à la recherche qu'au contrôle de la qualité. Nous proposons ici une méthode analytique facilement applicable en chromatographie liquide à haute pression (HPLC), 
qui permet de déterminer les trois sucres principaux, fructose, glucose et saccharose, et aussi le maltose parfois présent dans la GR. Les échantillons ont été dilués dans un mélange aqueux de méthanol $(3: 1)$, les protéines ont été précipitées par les réactifs de Carrez, les lipides éliminés par extraction au dichlorométhane. L'extrait a été analysé en HPLC avec détection de l'indice de réfraction (RID). On a étudié l'utilisation de plusieurs sucres comme norme de remplacement et le xylose est celui qui convient le mieux (Fig. 2). L' analyse en HPLC a été faite sur une colonne de $3,2 \times 250 \mathrm{~mm}$ avec particules de silice modifiées de $5 \mu \mathrm{m}$. La phase mobile est composée d'acétonitrile et d'eau (85:15), la colonne et le détecteur sont thermostatés à $30^{\circ} \mathrm{C}$, l'analyse qualitative et quantitative est basée sur l'injection d'un standard externe. Le temps d'élution est inférieur à $10 \mathrm{~min}$ et la limite de détection pour chaque sucre supérieure à $0,1 \mathrm{~g} / 100 \mathrm{~g}$. La méthode a été testée sur 97 échantillons. Les chromatogrammes obtenus n'ont pas montré d'interférences significatives (Fig. 1) et ont fourni des teneurs en sucres semblables à ceux mentionnés dans la littérature (Tab. III). Les tests de récupération effectués sur les échantillons de références (mélange de sucres en quantités connues traité comme un échantillon de GR) ont donné des résultats constants en quantité et en récupération. Les analyses à blanc ont fourni des chromatogrammes sans interférences méthodologiques. La reproductibilité de la méthode, testée en analysant 10 aliquots du même échantillon de GR, est satisfaisante pour des besoins de contrôle de la qualité. La méthode proposée est plus simple et plus rapide que les méthodes par GC et ne nécessite pas de standard interne. Elle ne souffre pas d'interférences de matrices, présente une bonne reproductibilité et permet une détermination quantitative des sucres qui convient pour un contrôle de routine de la qualité de la gelée royale.

gelée royale / sucres / HPLC

Zusammenfassung - Bestimmung von Zuckern im Gelée royale mit HPLC. Für Bienenprodukte mit Ausnahme von Honig gibt es keine international anerkannten Qualitätsstandards. Solche Standards wären bei Gelée royale besonders wichtig (GR), denn seine Produktion nimmt in den europäischen Ländern zu. Ein wichtiger Parameter für die Qualität von GR ist die Zusammensetzung von Karbohydraten, die bisher mit Gas Chromatographie (GC) bestimmt wurde. Für diese GC Methoden müssen die Karbohydrate gereinigt und zweimal derivatisiert werden, und es ist ein interner Standard notwendig. Die Methode ist deshalb mehr für die Forschung als für eine Qualitätskontrolle geeignet. Hier wird eine leicht anwendbare analytische Methode mit HPLC vorgeschlagen, die Bestimmung von 3 Hauptzuckern im GR, Fruktose, Glukose and Saccharose ermöglicht, zusätzlich auch von Maltose, der manchmal in GR vorkommt. Die Analyse wurde folgendermaßen durchgeführt: Lösung der Probe im Wasser/Methanol Gemisch (Verhältnis 3:1), Ausfällung der Proteine mit dem Carrez Reagenz, Entfernung der Lipide durch Extraktion mit Dichloromethan, Analyse des Extrakts mit HPLC mit der Refraktionsindex Detektion (RID). Mehrere Zucker wurden auf ihre Eigenschaften als Ersatzstandards überprüft. Xylose erwies sich als geeigneter Zucker (Abb. 2). Die HPLC Analyse wird mit einer $3,2 \times 250 \mathrm{~mm}$ Säule bestehend aus amino-modifizierten Silicapartikeln mit $5 \mu \mathrm{m}$ Durchmesser durchgeführt; die mobile Phase besteht aus Acetonitril:Wasserim Verhältnis von 85:15; die Säule und der RI Detektor werden konstant auf $30^{\circ} \mathrm{C}$ gehalten; die qualitative und quantitative Analyse basiert auf der Injektion eines externen Standards. Die Elutionszeit beträgt weniger als 10 Minuten, die Bestimmungsgrenzen für jeden Zucker des unbehandelten GR ist besser als 0,1 g/100 g. Diese Methode wurde bei 97 GR Proben getestet: die Chromatogramme hatten keine signifikanten Störungen in der Matrix (Abb. 1) and ergaben einen Gehalt an Zuckern, der mit Literaturwerten vergleichbar ist. (Tab. III). Wiederfindungstests, durchgeführt mit Referenzproben (Gemisch aus bekannten Zuckermengen bearbeitet wie eine GR Probe) erwiesen sich in Bezug auf Quantität und Wiederfindung als konstant. Blindproben ergaben Chromatogramme die frei von methodischen Störungen waren. Die Reproduzierbarkeit der Methode, getestet durch Analyse von 10 Teilproben einer GR Probe, erwies sich als ausreichend für Erfordernisse einer Qualitätskontrolle. Die vorgeschlagene Methode ist einfacher und schneller als die GC Methoden und benötigt keinen internen Standard. Sie erweist sich frei von Matrixstörungen, ergibt eine gute Wiederholbarkeit und ermöglicht so die quantitative Bestimmung von Zuckern, die für eine Routine von Qualitätskontrollen für GR ausreicht.

\section{Gelée royale / Zucker / HPLC}

\section{REFERENCES}

Bloodworth B.C., Harn C.S., Hock C.T., Boon Y.O. (1995) Liquid chromatographic determination of trans-10-hydroxy-2-decenoic acid content of commercial products containing royal jelly, J. A.O.A.C. Int. 78, 1019-1023.

Bogdanov S., Baumann E. (1988) Bestimmung von Honigzuckern mit HPLC, Mitt. Geb. Lebensm. Hyg. 79, 198-206.

Bogdanov S., Martin P., Lüllmann C. (1997a) Harmonised methods of the European Honey Commission. Determination of hydroxymethylfurfural after White, Apidologie (extra issue), 25-27.

Bogdanov S., Martin P., Lüllmann C. (1997b) Harmonised methods of the European Honey Commission. Determination of sugars by HPLC, Apidologie (extra issue), 42-44. 
Bogdanov S., Bieri K., Gremaud G., Känzig A., Seiler K., Stöckli H., Zürcher K. (2004) Gelée Royale, in: Manuel suisse des denrées alimentaires, Chap. 23C, [online] http://www.bag.admin.ch/ slmb/online/d/SLMB/Data\%20SLMB_MSDA/ Version\%20F/23C_Gelee\%20royale.pdf (accessed on 21 October 2005).

Codex Alimentarius (2001) Codex Standard 12, Revised Codex Standard for honey, -1981, Rev. 2, 7 p., [online] http://www.codexalimentarius.net/ download/standards/310/CXS_012e.pdf (accessed on 18 October 2005).

European Commission (2002) Council Directive 2001/110/EC of 20 December 2001 concerning honey, Official J. Eur. Communities Jan. 12th 2002, L10, pp. 47-52 [online], http://europa.eu.int/ eur-lex/pri/en/oj/dat/2002/1_010/1 01020020112en00470052.pdf (accessed on 18 October 2005).

IHC (2003) Minutes of the annual general meeting of International Honey Commission, Ljubljana 2003 [online], http://www.apis.admin.ch/english/host/ pdf/honey/ljubljana.pdf (accessed on 18 October 2005).
Lercker G., Caboni M.F., Vecchi M.A., Sabatini A.G., Nanetti A. (1992) Caratterizzazione dei principali costituenti della gelatina reale, Apicoltura 8, 27-37.

Lercker G., Savioli S., Vecchi M.A., Sabatini A.G., Nanetti A., Piana L. (1986) Carbohydrate determination of royal jelly by high resolution gas chromatography (HRGC), Food Chem. 19, 255-264.

Piana L. (1996) Royal jelly, in: Krell R. (Ed.), Value added products from beekeeping, FAO Agric. Serv. Bull. 124, 195-226.

Pourtallier J., Davico R., Rognone M.C. (1990) Les analyses dans le contrôle de pureté de la gelée royale, L'Abeille de France 753, 405-407.

Serra Bonvehi J. (1991) Study of adulteration of royal jelly with other honey bee products and water, Prod. Sanidad Anim. 6, 99-111.

Serra Bonvehi J. (1992) Azucares, acidez y pH de la jalea real, Anal. Bromatol. 44, 65-69.

Tourn M.L., Lombard A., Belliardo F., Buffa M. (1980) Quantitative analysis of carbohydrates and organic acids in honeydew, honey and royal jelly by enzymic methods, J. Apic. Res. 19, 144-146. 